\title{
LGBT TOURISM IN PUERTO VALLARTA: SOURCE OF FOREIGN EXCHANGE OR A BREACH OF ETHICS AND MORALS IN MEXICAN SOCIETY? REFLECTIONS OF AN ETHNOGRAPHY
}

\author{
JESÚS OTONIEL SOSA RODRÍGUEZ, ADRIANA DEL CARMEN BAUTISTA \\ HERNÁNDEZ, NUCHNUDEE CHAISATIT
}

\begin{abstract}
:
As of 2013 in Mexico, the creation, support and development of the LGBT tourist segment were established into the Mexican federal government policies, which has not been consolidated besides lacking of statistical and economic data so its socioeconomic impact is known. The objective of this research is to reflect on the social and economic effect generated by an LGBT friendly tourist destination resulting from the touristic practices that take place in Puerto Vallarta, Jalisco.

This beach destination is considered the most important LGBT tourist destination in the country due to the amount of economic income it generates and the touristic infrastructure that has been developed. Some considerations are made on the relationship between the expenditure generated by tourists and the income received by residents, as well as its socio-environmental impact. The methodology used is of a mixed nature, emphasizing the integration of economic data in a quantitative way besides ethnography carried out in the destination in a qualitative way.

The results of this social phenomenon called LGBT Tourism finally unleashed a synergy and power relations between the different actors involved in Puerto Vallarta: government, businessmen, civil associations, residents and to a lesser extent tourist.
\end{abstract}

\section{Keywords:}

LGBT tourism, tourist spaces, ethics, power relations, ethnography.

JEL Classification: L38, L83, D74

\section{Authors:}

JESÚS OTONIEL SOSA RODRÍGUEZ, University of Colima, Mexico, Email: otonielsosa@ucol.mx ADRIANA DEL CARMEN BAUTISTA HERNÁNDEZ, University of Colima, Mexico, Email: acbautista@ucol.mx NUCHNUDEE CHAISATIT, University of Colima, Mexico, Email: nuchnudee@ucol.mx

\section{Citation:}

JESÚS OTONIEL SOSA RODRÍGUEZ, ADRIANA DEL CARMEN BAUTISTA HERNÁNDEZ, NUCHNUDEE CHAISATIT (2021). LGBT tourism in Puerto Vallarta: source of foreign exchange or a breach of ethics and morals in Mexican society? Reflections of an ethnography. International Journal of Social Sciences, Vol. X(1), pp. 74-87., 10.52950/SS.2021.10.1.004 
Society in Puerto Vallarta has been framed in various social changes. It's been about one hundred years of its configuration as a city, more than half of those years have witnessed a social phenomenon called tourism, which modified practices and spaces, but, above all, it shaped new power relations along the territory, resulting from relations of production and significance that link tourism and sexuality through what we have defined as gay tourism.

Puerto Vallarta began as a small fishing and salt-producing town until becoming a tourist port of national and international relevance, transformation which brought along significant changes among the relationships of those actor's that shaped the space in past times, these transitions reveal how the federal government, the government of the state of Jalisco, the municipal government and the businessmen of Vallarta would become the actors that would establish the rules of the game in the tourism realm.

After decades, year 2020 finally portrays a distinctive spatial-temporal context for Puerto Vallarta transforming it into a different socio-territorial space which allows LGBT + community social practices, especially for gays that in some other national and internationals contexts are not allowed. These changes are the result of the resistance of the LGBT + community that has organized and resists through different strategies carried out by actors, such as businessmen and associations, however, the LGBT + community continues being stigmatized and singled out for generating income to society, but at the same time "being immoral" in the eyes of Mexican society that considers that its social practices not an example to follow.

This socio-economic tension frames the research on this social phenomenon called gay tourism or LGBT tourism as referred by some authors and is a reference to the main author's PHD dissertation named : "Configuration of LGBT friendly tourist spaces, the Puerto Vallarta case, Jalisco Mexico "; which is structured in three following sections: 1) The complexity and the mixed method in the interdisciplinary research of LGBT tourism; 2) Ethics, interdiscipline and its relationship with the economic activity of "LGBT Friendly" tourism and; 3)Environmental and sustainable edges and potentialities of urban development in the tourist area of Puerto Vallarta, Jalisco.

\section{1) Complexity and the mixed method in interdisciplinary research on LGBT tourism}

Analyzing complex problems results in (un) thinking about the ways in which social research in tourism has been worked, to think that tourism approached from a particular discipline would solve complex implications is to fall into an error, approaching tourism as a social phenomenon implies an interdisciplinary and / or transdisciplinary challenge. Luengo (2012) proposes to move from an interdiscipline to a transdiscipline that allows solving the "real" social problems, that is, "it concerns both the description and analysis of the problematic process from the scientific point of view of the social actors involved, as well as strategies to solve the problem "(Luengo, 2012: 17).

In this regard, to solve the social issues derived from the economic phenomenon of tourism it is necessary to approach them from the paradigm of complexity since, "the knowledge breakthrough... takes place through revolutions, ruptures, breaks or bifurcations "so that complexity sciences will be able to solve it (Maldonado, 2016). 
What is needed to transform today's society into a more desirable one is planning the solution of the problems that are faced with the assistance of others, breaking down boundaries by working in partnership with various relevant disciplines and changing the way we think and address scientific knowledge

Another proposal to (re) think about the way in which the process of Configuration of "LGBT friendly" tourist spaces was studied is the one carried out by Cortés, Escobar and González (2010), which proposes approaching the social studies from mixed research, that is, leaving aside the fact that the qualitative or quantitative method is better, but thinking that they complement each other, gathering elements of both methodologies will result in a better understanding and explanation of the social realities immersed in the touristic space that want to be explained (Rubalcaba, cited in Gil, 2019).

It is important to point out that beyond the complementarity that the qualitative and quantitative method can have, the interesting thing is to clear out the realities that have been set out to decipher; Although the quantitative method may have approaches that let us come near an explanation of reality, the truth is that the qualitative method will always have other explanations that generate knowledge that hasn't been previously considered by the theory, in other words, it will have some other form (s) of explaining complex realities. I consider that Tashakkori and Teddlie's (1998) proposal regarding mixed model studies is congruent with this research project since it implies a more complex

is compatible with my research project since it implies a more profound degree of insight, being that the reason why it was decided that Ethnography and quantitative analysis of social networks will complement each other and will also help to explain the reality of the LGBTfriendly tourist area of Puerto Vallarta

To put it another way, and as King (1994) points out, it's about is about a disciplined thought, that is, using mixed methods or making theoretical inferences is not enough, since it is usually done in an imperfect way. It is about carrying out valid and reliable researches, considering that the data collection, interpretation and analysis techniques must maintain a high degree of rigor and that even so, must consider keeping a certain degree of uncertainty in the conclusions. Therefore, leaving the "war of methodologies" in the past and think about mixed models is a great success, since the well-founded contributions to apply it in empirical research are not usually discussed and authors such as Cortés, Escobar González, Tassakkori, Teddlie and King, open up this possibility to us through reflection. Interdiscipline as such cannot be thought from a war of paradigms or methodologies but viewing its complementarity or joined application and dialoguing to one another to obtain a more complete explanations of complex research issues that we face such as the one that concerns this one.

The research carried out was mixed and interdisciplinary, however this particular article is based on the ethnography carried out in Puerto Vallarta, during the period 2015-2019, derived from a PHD dissertation that allowed ethnographic conversations and interviews to be held, as well as conduct ethnographic observation and documentary research.

A great amount of the information collected was due to the joining of one of the authors of this research as a member of the Vallarta community. Being present and active in the community 
allowed him to be part of some organizations leaded by the actors that appear within the discourse presented, the invitations received were accepted as part of the ethnographic task of the researcher ${ }^{1}$.

\section{2) Ethics, interdiscipline and its relationship with the economic activity of "LGBT Friendly" tourism}

When talking about ethics, the term is always discussed and a standpoint is taken without being able to have a theoretical position in its regard and on many occasions we argue to a wrong concept, we agree with Arendt (2007) in the ethical conceptualization: "...It is never if the individual is good, but if his behavior is good for the world in which he lives. The center of interest is the world and not the self "(Arendt, 2007: 154). When discussing ethics, we must think of more than a" concept "that goes through the sense of freedom with boundaries, building communities and collective responsibility, since it is basically the citizen (who lives in a community) and so is the one who performs for or to the detriment of the world in which he lives.

The criticisms to capitalism exposed by Bruckner (2003) make us reflect on the forms of domination and the elements that have perverted the system, preventing it of working properly, then, what does the unequal distribution of the wealth and the lack of valuation of the quality of human life allows to happen? The question is not whether it is good or bad, because to us, it is crystal clear that this mechanism can be modified or eliminated, but the question that needs to be asked is whether we should withdraw ourselves from the system? Or be cynical and think about the ability of changing and modifying since withdrawal is just not enough to achieve the needed changes, as suggested by Arendt, we have a collective responsibility. But what does that mean? if understood as proposed

But what is collective responsibility? if we understand it as it is proposed:

"... to be held responsible for something that I have not done, and the reason for my responsibility must be my belonging to a collective group that no voluntary act of mine can dissolve, in other words, a type of membership totally different from a commercial association, which I can dissolve whenever I want "(Arendt, 2007: 152-153)

As a matter of fact, we cannot evade our responsibility by "ceasing to act in favor or against capitalism" with the thought that my community's conditions will improve, because, if we wanted to evade this responsibility, we would take a stand on the concerning for "the I" and we would stop being interested in the world's we live collective wellbeing and we would fall into a lack of ethics.

In this context, tourism as a socioeconomic activity that is "intended" for a certain minority such as the LGBT + community, encounters ethical implications that cannot be ignored, the first being

\footnotetext{
1 The author of this research lived in Puerto Vallarta from September 2017 to October 2018, however, he was intermittently living from $2015-2017$ and $2018-219$ to carry out the ethnographic process. During that time, it collaborated with two associations (ACT LGBT, SETAC).
} 
the value judgment concerning same sexual orientation and gender identity; for the West side of the world and under the Jewish-Christian "rules" (as well as in other religions and societies) being homosexual is "bad" (lacking of morality) for as in these, the moralistic ideas of marriage, monogamy, sex not as a practice fulfills reproduction but as a way of obtaining pleasure, and succumbing to desire and passion. The first question that arises is, in a traditional / macho culture like Mexican, why should touristic spaces for gays be created? If for the prevailing society they lack ethics and morals, the answer is also related to ethics.

The researchers' hypothesis is: they have to be apart from the society so that they do not corrupt the currently admitted socio-sexual order, that way certain economic profit "can be obtained" since they are money generators and they spend it only on them (since they have no family to support), but just keeping them in spaces "intended for them". Therefore, a discourse of nondiscrimination that national wide considers eight places in the as "LGBT friendly tourist destinations" become a device of power and control of sexuality that seems to turn these spaces into "invisible ghettos."1

The proposal made by the French sociologist Loïc Wacquant, who coined the sociological construction of the ghetto, helps understanding it, since it points out the purposes and elements that constitute it:

... socio-organizational instrument that uses the space to reconcile two antinomian purposes: to maximize material profits obtained from a group considered tainted and defiled, and to minimize intimate contact with its members to ward off the threat of corrosion and the symbolic passing along that they carry with them ... The four elements that constitute the ghetto are: stigma, restriction, spatial confinement and institutional pigeonhole (Wacquant, 2004: 2)

Wagner (1997) proposes that it is precisely in the condition of "modernity" in which men have the ability and obligation of ruling their own lives, however, it is worth asking: is the man able to discern that he is trapped in a domination game in which a "mirror" has been exchanged for "gold", when exchanging the "money for his own freedom"? It seems that we are in an impasse from which we cannot see the way out. In other words, we recognize that we might be in the midst of a transition, but since an exact answer of which path should be taken towards the "next" destination, the destination seems blurred and we go back to the same place again.

Wagner (1997) himself quotes Giddens to establish that institutions are these set of rules and resources that seem permanent and they are often endowed with a great spatial-temporal extension that would be far from restricting the human action, but instead would make it possible, in this scenario it is worth asking whether modern institutions effectively promote different "freedoms" that allow the development of new social practices, or is it that the members of the society studied ( take part in)" the reproduction and transformation of these institutions through their daily activities the reproduction "(Wagner, 1997: 18)

\footnotetext{
1 Sosa (2019) considers it as an invisible ghetto, because it is not intended as a ghetto, but it has certain characteristics that point towards that, and invisible because apparently the space is not officially visible in society
} 
"There are in fact more actors and bigger performing spaces, but in an extremely stratified and inevitably global context" (Wagner, 1997: 324), this phrase reminds of the unequal distribution of power due to society society's structuring that allows coercion, oppression and exclusion in a tourist destination, touristic practices carried out in there lead to think not only of LGBT + tourists, as a minority, but also of the large quantity of workers who work there or who could be exploited for " capitalists" purposes and where the effects of a socioeconomic phenomenon such as tourism could be a benefit to a few and impact negatively on members of the local host community or on tourists that are immersed in the space referred.

Another question that arises is, how to change the mechanism of capitalism or modify it, if the capability that resides in political action has been disabled ?, Wagner (1997), proposes an encouraging answer: "create the capability for political action by reestablishing a synergy between social identities, political boundaries and social practices ", however, the question remains: how to achieve this synergy? in contexts of unequal power domination, where the institutions established by this same structure seem to constrain and not enable the achieving of changes needed for reorganizing.

Speaking of Vallarta, this response was found as a result of the resistance of the LGBT + community that is organized and resists through different strategies carried out by actors, such as businessmen and civil associations, whom have been able to articulate truthful discourses that shape the existing power relationships in Puerto Vallarta, where the economic sphere (entrepreneur and businessmen) but also Vallarta locals are supported through LGBT + associations, residents 'associations, entrepreneurial and through synergy even the municipal council as a governing entity.

Facing domination, the overpowered turn to a hopeful discourse, when we are told that "we all" have access to universal human rights, however, when speaking of different welfare regimes (universalist, conservative-corporatist, dual) different types of citizens are identified, again depending on the country where we were born and where the current "welfare" regime will become the way of living and through which we will be "organized" in society, at the end of the day, the different regimes are designed so a society can be controlled through a tolerated extractionism and a precarious citizenship.

Another questioning related to the touristic phenomenon is to think, if in the tourist area promotes the precariousness of the receiving community, understanding that "precariousness does not mean the impossibility of accessing resources, but the insecurity in their availability" Vara (206: 106), Even in countries like Mexico, where natural resources are enough to overcome the various situations they find themselves in, Vara establishes that it is not only about having access, the real question is ... how long will they be available and would it be possible to have access to them?. In Mexico, the scene is not "more promising" than in other countries, due to the dualistic state of welfare procured conditions that we live in, are experiencing a welfare regime that only uncovers how we are "different types of citizens ", stratified, hierarchical and pointed out by our economic and employment status (Barba and Valencia, 2013), establishing the motto:" tell me what you work in and I will tell you what type of social security you deserve ",triggering the question: How long will we allow human rights to be violated and blurred in Mexico? And to what extent does tourism contribute to the precariousness of the host community? 
That is the exact problem that needs to be addressed and solved; ethnography as a methodological proposal derived from anthropology, gives us a guideline for solving the combined conflict that exists with other scientific methods, so it is not about eradicating capitalism or making major modifications, it is about visiting other communities getting to know them, highlight their needs and their action capability, in other words, one must adress to cultural references (San Román, 1996) to understand the ways in which communities "want" or "can" organize themselves so they can handle their economy and achieve a socioeconomic development based on social development and environmental care.

Social development and environmental deterioration is a collective responsibility, we cannot evade, since achieving changes at a global level depends on all the citizens of the different States, it is irresponsible and unethical to think that the governments of a country protect its citizens, but leave the non-citizens in famine and in between wars. Rethinking socio-economic development in our days considering ethics as a basis should not be a suggestion, but a requirement. The following is a special section related to environment and urban development of the studied tourist destination.

\section{3) Boundaries and environmental and sustainable potentialities of urban development in the tourist area of Puerto Vallarta, Jalisco}

"The concept of global warming was created by and for the Chinese in order to make US manufacturing non-competitive ... We can't destroy the competitiveness of our factories in order to prepare for nonexistent global warming. China is thrilled with us! " Trump (2012)

We begin this section with this quote, not because we the position we stand on is for or against Trump, but because it is hideous how people (including Trump) think that climate change and its consequences may be a Chinese invention or Hollywood science fiction, and therefore do not attend to the environmental effects that we have caused in pursuit of some regions' economic development, but at the same time we devastate the entire world.

Sarukhán and White (2005), presented a report on ecosystems assessment and human well-fare and they made clear the following four alarming issues: 1) there is a rapid and extensive transformation with a negative impact on ecosystems during the last 50 years, caused by human beings; 2) the net profits in human well-being and economic development, achieved based on ecosystems, will considerably decrease due its irrational use; 3 ) the deterioration of ecosystem services could worsen during the first half of the 21 st century; 4) The challenge is to reverse the mentioned deterioration to continue meeting demands, but trough positive synergies with other ecosystems.

The presented and detailed conclusions confirm what has been said for decades that the future would be and the future has reached us, we live in a world in which we face challenges such as climate change, the loss of biodiversity and soil degradation, as a result of the doubling of the world's population and world economic growth (more than six times) over the past 50 years, the main question is what is ahead and what to do?

There is no control on the ecosystems depredation, which for logical reasons will entail an ecological disaster exacerbated by the "economic profit" that this represents, that is, the business 
of the future (our present) is "human well-being", the large corporations will seek to compensate for the damages caused by the human being at the moment when their businesses are directly impacted, but that will have a cost and a price, we will go from do you want to have drinking water, clean air, sustainable ecosystems? Do you have enough to pay and being entitled to enjoy it? Because our reality is that there is more and more famine, disease, zero human well-being and even death, as the World Health Organization pointed out in 2016, air pollution killed in 2012 more than 7 million people (WHO, 2016), if clear and instrumental policies are not thought out at a global level, nor even all the existing economic resources will make possible to reverse the damage done to the environment.

Thinking about paying or compensating for "exploiting" or the usage of hydrographic basins, aesthetic beauty, biodiversity and carbon (Cordero et al., 2008), can generate some other social inequity issues and increase poverty levels, therefore the concept / method of elasticity proposed by Daw et al. (2016), although it does not provide a single solution, allows through an interdisciplinary analysis and a policy study, to move forwad in the study of ecosystems and human well-being that it could be applied in Puerto Vallarta, Jalisco, addressing the degradation of ecosystems due to tourism.

Thinking about either the nation's or the world's economic development implies asking, without exception, what is affected in environmental terms? When undertaking specific socioeconomic activities, just thinking about payment for environmental services or how to compensate for them is not enough, though it is a great advance, it's insufficient for a problem so complex that for obvious reasons needs to be approached either inter / transdisciplinary or with groups of experts in "think tanks "idea laboratories (Sarukán \& White, 2005; Cordero et al, 2008; Daw et al., 2016), however, there is a responsibility to solving complex problems integrating the environment, through an interdisciplinary approach, in our projects of investigation.

In the case of the ethnographic research carried out in Puerto Vallarta, Jalisco, it is considered that the environmental effects are not taken into account the way they should be , pollution in public spaces (beaches, sea, parks, boardwalk) is one of the most visible effects when visiting the destination, however it is remedied through cleaning campaigns that are not enough being the awareness of locals and tourists should be the main target that need to be reinforced considering that a critical attitude for environmental caring is not perceived, but rather of extractivism pure of the tourist space.

Another effect that has to be examined is the bearing capacity of the soils that are used for touristic activities, since it is proven that the use of ATVs, horses and even tourist walks on guided tours damage the first layer of the soil and erode it in such in such a way that it may take decades to recover it.

Urbanization issues in regards to the accelerated and excessive construction of residential buildings and hotels, in the "romantic zone" (LGBT friendly space) of the destination, is the one environmental factor that stands out the most for its importance, although it seems to go unnoticed; According to the Eroski foundation (2016), "buildings are one cause of the main environmental problems, an average cost of three tons of materials is calculated per square meter built", the answer we look for is: who can pay for those apartments? versus who doesn't 
even have a place to live? and which ecosystems are being destroyed or degraded to obtain those tons of materials? What are the implications for the touristic destination in terms of ecosystems and human well-being? Urbanization as a phenomenon that includes the construction of buildings which are is wreaking havoc on the environment, only in the tourist area that was studied, these buildings represent more than fifty percent of the construction in the area.

"... there is a chaotic development in the urban zones of Mexico and Jalisco ... partly, due to, the rapid population growth and migration to territories not suitable to accommodate the growing demand for housing and other public services" UN-Habitat (2015: 16)

Throughout many years, burgeoning growth in countries like Mexico based their economic development on agriculture, however, with processes like industrialization and globalization, agriculture was shifted as an income and jobs generating activity and the forgotten, in such a way that many people had to leave their rural communities (considered by INEGI for having up to 2,500 people) and migrate to the cities in search of "new opportunities "of living and in some cases of barely surviving. One of those cases in Puerto Vallarta, a territory to which people have migrated in order to join the tourism industry and generate income that allows them to sustain themselves.

INEGI reports that in just sixty years, 1950-2010, urban communities population in Mexico almost doubled, from $42.6 \%$ to $77.8 \%$ in 2010 , which means exponential population growth in cities, that without a doubt has occured "disorderly" and has not been channeled with forethought by the governors in turn, that is, the possibility of increasing the services offered was not considered, in some cases they haven't even increased according to rate at which the population increased, which has an economic, social and environmental impact on "overpopulated" cities that are causing an imbalance in the production-consumption model and putting in stake the societynature system.

According to the National Urban Development Plan 2014-2018, published in 2014, six objectives were proposed, which would take "Mexico to its maximum potential":

1) Control the expansion of urban areas and reinforce cities so the quality of life of its inhabitants improves; 2) Strengthen an urban development model that generates wellbeing for citizens, guaranteeing social, economic and environmental sustainability; 3) Design and implement regulatory, fiscal, administrative, and control instruments for soil management; 4) Promote a sustainable mobility policy that guarantees the quality, availability, connectivity and accessibility of urban trips; 5) Avoid human settlements in risk areas and reduce the vulnerability of the urban population to natural disasters, and; 6) Reinforce the National Policy for Regional Development based on local vocations and economic potential.

The interesting thing would be to decipher what the government means when referring to the "maximum potential", since it is not clear, and in its objectives it advises that models and instruments must be created to regulate the quality of life, generate human well-being and "enhance local economies" Therefore, each city or rural population should follow these "directions" in order to erase the challenges that the urban-rural dichotomy represents. In fact, in 
the UN-Habitat report (2015), prosperity is considered with the following six dimensions: 1. Productivity; 2. Infrastructure; 3. Quality of life; 4. Equity and Social Inclusion; 5. Environmental Sustainability, and; 6. Governance and Legislation and proposes to measure the city's progress according to the Index of the Prosperous City, through "quantitative" indicators that at the same time "are conjugated" with the Millennium Development Goals and through which the maximum well-being and progress for cities in the world is sought to be achieved and of course, if possible to compare them with global "big cities" that indeed do not have the same Mexican context regarding the migratory flow from the countryside to the city and agriculture development and "livestock in some cases " inherent to other activities in the cities.

Does the touristic territory of Puerto Vallarta allow that "maximum potential" described by the federal government when complying with the six dimensions of prosperity that the tourism phenomenon offers when in an urban context? The answer is not immediate, although the effects on job creation, foreign investment, and foreign currency reception are clear, the social effects that are integrated into the host community are not clear, since the analysis of tourism is generally done as of the economic revenue and not as of the socio-environmental effects that are generated.

Mendo (2012), in his applied study of the City Development Index, measures the average level of well-being of the inhabitants based on their access to infrastructure and urban facilities, he makes a comparison of the entire Western region of Mexico, comparing metropolitan areas, managing to highlight the great differences that exist in an area that could be seen as homogeneously throughout the region, however, it was not like that and two interesting things pop out what is interesting are two things, 1) that the model could be contrasted with elements or even some other qualitative model to get to know "that well-being" that until now had been measured numerically and; 2) that the results, as the author mentions, should be "known, discussed, disclosed ... when channeling regional development plans, programs and projects" (Mendo, 2012: 23), so that the authorities and decision makers knew about them, because, as a matter of fact, the main impact is for the inhabitants of the studied areas, as it happens with tourism as a regional development project and its effects on the social welfare of the community

It is through agrodiversity that we seek to respond to the crisis that Morales, Velázquez and Ochoa (2012) visualize along society and nature, society-society relations and metropolis-rural spaces. They propose a concept of "generating processes" through interdisciplinary and political ecology that would help to rectify the damage that has been caused to nature and therefore to the human being himself, the proposal of Morales, Velázquez and Ochoa (2012) can be useful to counteract the "negative" effects of tourism in the city of Vallarta since by increasing processes that generate political ecology such as urban agriculture among others, it would contribute to compensate to a great extent the effects of environmental and sustainable deterioration generated by the touristic phenomenon.

Finally, it is worth contextualizing each of the cases, even though we know that there are some in common ideas, reality is that each dichotomy of urban-rural space represents a sole study to be carried out, each one with clear and contextualized proposals in space-time, referring to Puerto Vallarta, there are many rural "urban" communities near the touristic area which could be integrated through agricultural production that could be consumed by local hotels and restaurants. 


\section{Conclusions}

The world economy has not fully recovered from the economic crisis that occurred in 2008 and it is already facing new economic crisis phenomena derived from the Covid19 pandemic, which will have negative effects on society and that for the moment it is not observed that States (as guarantors of stability within the nations) are taking either political or social actions to solve them.

The Mexican scene is exceptional since the triumph of Donald Trump in the presidency of the United States of America and adding the crisis generated by the COVID 19 pandemic, the forecast is viewed as "complicated" for Mexican society in all aspects, in addition, the depreciation of the Mexican peso makes clear reference to the instability "of what awaits for Mexico", from the moment Trump's winning became public until this day, our country's currency has not stopped suffering havoc, even with the raising interest raise approved by the Bank of Mexico; The Mexican scene seems "dark" in the economic realm since it depends on the foreign exchange received from exports and more than eighty percent are sent to the United States as well as the remittances that Mexicans send (legal and illegal) in the United States to Mexico, which represented 24,785 million dollars total in 2015, becoming the second source of external income for the country, just followed by foreign direct investment; tourism ranked third with an economic income of more than 17,000 million dollars (Banco de México, 2016).

The Mexican context is "on hold" that is, we will not know where the economy will go until we review the policies that the magnate and president of the United States will impose through the office and congresses, the expectation is great, because "adjustments" to the Free Trade Agreement (FTA) now TMEC, could decrease the level of exports to that country drastically, if so the dollar would depreciate even more and it is almost a fact that investments in Mexico would collapse as the main investor in the country is also States United.

So much is said about the policies that Trump will establish and their possible effects they will have on the Mexican economy, a "solution" to this announced catastrophe will be to boost the international tourism that is received, considering the appreciation the dollar has.

Unfortunately, with the arrival and speech of President Trump, there will be some other consequences that are already happening, such as the fear established in the "illegals" who live in that country, as well as minorities such as: disabled, women and of course the LGBT community. The American businessman attacked these groups during his campaign and has insisted that "punitive" measures will be taken in this regard, that would imply a setback in human and civil rights "achieved" worldwide, being the LGBT case an example. His main political ally seems to be Vladimir Putin who in 2013 sponsored punitive legal measures against the "propaganda of non-traditional sexual relations", in other words, since 2013 in Russia the process of discrimination against homosexuals has been increasing, this could be replicated in the United States with a "discourse that legitimizes" such practices.Finally, the internal context in Mexico does not help the LGBT community, just a day later and after the smoke screen generated by Trump's triumph, Mexican President, Enrique Peña Nieto, banned an initiative, that promoted the non-discrimination for same-sex couples and even proposed modifying the law regarding marriages, adoption and even gender change, in addition with the current president Andrés Manuel López Obrador the situation becomes more complicated, since even in an official statement a special mention about the possibility of disappearing the National Council to Prevent 
Discrimination (CONPARED) is made, being this institution the one that helps preventing discrimination against the LGBT + community in Mexico.

As you can see, the scene is not encouraging, dozens of movements are emerging due to the discourse and actions of Trump and President López Obrador, however, it is thought that the social sense of the economy should recover, and therefore and "smoothing" of tourism for people of the LGBT + community, but at the same time the social implications of the economic income from tourism in Mexico need to be analyzed, solving the dispute between increasing foreign exchange through LGBT tourism or maintaining a "tidy" Socio-sexual realm in places like Puerto Vallarta?.

\section{References}

ARENDT, H. (2001). “La condición humana”, Paidós, Barcelona.

ARENDT, H. (2007). "Responsabilidad y juicio”, Paidós, Barcelona.

BARBA, C. and VALENCIA, E. (2013). La transición del Régimen de Bienestar Mexicano: Entre el dualismo y las reformas liberales. Revista Uruguaya de Ciencia Política, vol. 22, núm 2, 2013, pp. 47-76. Instituto de Ciencia Política.

BARBA, C. and VALENCIA, E. (S/F). Varietis of Universalism in the Trajectories of Health Policies in Mexico and Brazil.

BRUCKNER, P. (2003). "Miseria de la prosperidad. La religión del mercado y sus enemigos", Tusquets, Barcelona.

CORDERO, D.; MORENO, A. and KOSMUS, M. (2008). Manual para el desarrollo de mecanismos de pago/compensación por servicios ambientales. Equipo Regional de Competencia y Programa GESOREN, GTZ-Ecuador.

CORTÉS, F. (2008). "Selección no aleatoria y validez", en Cortés Fernando, Agustín Escobar y Mercedes González de la Rocha, Método Científico y Política Social: A propósito de las evaluaciones cualitativas de programas sociales, El Colegio de México, México.

DAW, T.; HICKS, C; K. BROWN, K; CHAIGNEAU, T.; JANUCHOWSKI-HARTLEY, F.:, CHEUNG, W.; ROSENDO, S.; CRONA, B.; ET AL. (2016). Elasticity in ecosystem services: exploring the variable relationship between ecosystems and human well-being. Ecology and Society 21(2):11. https://doi.org/10.5751/ES-08173-210211

EROSKI CONSUMER. (2016). "Impacto ambiental de los edificios" http://www.consumer.es/web/es/medio_ambiente/urbano/2005/10/20/146299.php Consultado el 24 de septiembre de 2016

GIL, A. (2009). Reseña de "Método Científico y Política Social: A propósito de las evaluaciones cualitativas de programas sociales" de Fernando Cortés, Agustín Escobar y Mercedes González de la Rocha, 
Estudios Sociológicos, vol. XXVII, núm. 81, septiembre-diciembre, 2009, pp. 1061-1070. El Colegio de México, México.

INEGI. (2016). Volumen y crecimiento. Población total según tamaño de localidad para cada entidad federativa, 2010 Consultado en: 24 de noviembre de 2016.

KING, K. Y VERBA. (1994). Designing Social Inquiry, New Jersey: Princeton University Press. https://doi.org/10.1515/9781400821211

LUENGO, E. (2012). Interdisciplina y transdisciplina: aportes desde la investigación y la intervención social, "La transdisciplina y sus desafíos a la universidad". Complexus 2, Cuadernos de avance del Centro de Investigación y Formación Social, México, ITESO

LUENGO, E. (2014). El conocimiento de lo social I. Principios para pensar su complejidad. México, ITESO

MALDONADO, C. (2016). Complejidad de las ciencias sociales. Y de otras ciencias y disciplinas, Bogotá, Ediciones desde abajo.

MENDO, A.. (2012). Índice de Desarrollo de la Ciudad. Revista Ciudades, vol. 93, núm 1, 2012, pp. 19-23. Red de Investigación Urbana A.C..

MORALES J.; VELAZQUEZ, L. and OCHOA, H. (2012) Interdisciplina y Ecología Política: algunas reflexiones desde la investigación en "Complexus Saberes Entretejidos" Volumen 2 Publicación del Centro de Investigación y Formación Social ITESO

MORALES, J.; ALVARADO, E. and VÉLEZ, L. (2013). La agricultura periurbana y las alternativas hacia la sustentabilidad en la Zona Conurbada de Guadalajara, Jalisco, México.

ONU-HÁBITAT. (2015). Guadalajara Metrópolis Próspera: Antecedente metodológicos del Índice de la Ciudad Próspera.

ORGANIZACIÓN MUNDIAL DE LA SALUD. (2016). "7 millones de muertes cada año debidas a la contaminación atmosférica"

SAN ROMÁN, T. (1996). “Los muros de la separación”, Tecnos, Madrid.

SARUKHÁN, J.; WHYTE., A. (2005). Ecosystems and human well-being. Synthesis. Myllennium Ecosystem Assssment.

SOSA, J. (2019). Configuración de espacios turísticos LGBT friendly. Caso: Puerto Vallarta, Jalisco. (Doctoral dissertation, ITESO University ,Guadalajara, México). Retrieved from https://hdl.handle.net/11117/6214

TASHAKKORI and TEDDLIE. (1998). Mixed Methodology, California: Sage.

VARA, M. (2006). "Precarización de la existencia y huelga de cuidados". En: Vara, María de Jesús (Coord.). Estudios sobre género y economía. AKAL. Madrid, España. Pp. 104-135.

WAGNER, P. (1997). "Sociología de la modernidad", Herder, Barcelona. 